\title{
The Importance of Community's Involvement in Park Management towards Sustainable Livelihoods
}

\author{
Nor Azlina Abu Bakar1, Geoffrey Wall2 \\ ${ }^{1}$ Faculty of Design and Architecture, \\ Universiti Putra Malaysia, Malaysia \\ ${ }^{2}$ Faculty of Environment, \\ University of Waterloo, Canada \\ ab_azlina@upm.edu.my, wall_geoffrey@hotmail.com
}

\begin{abstract}
This study investigates the impacts of park establishment on communities and how institutional structures, such as customary laws, can influence communities' involvement in ecotourism. A sustainable livelihoods (SL) approach was adopted as a framework to analyze the relationships among institutional processes and organizational structures (i.e. NCR, institutional arrangement), livelihood strategies and livelihood outcomes. Although Tun Sakaran Marine Park contains beautiful islands, and tourism is the main economic activity, surprisingly, this study found out that local communities are not involved in tourism. Institutional support should be strengthened if ecotourism is to become a livelihood strategy for communities in TSMP.
\end{abstract}

Keywords: ecotourism; sustainable livelihoods; institutional arrangement; marine park

eISSN 2398-4279 (C 2019. The Authors. Published for AMER ABRA cE-Bs by e-International Publishing House, Ltd., UK. This is an open access article under the CC BY-NC-ND license (http://creativecommons.org/licenses/by-nc-nd/4.0/). Peer-review under responsibility of AMER (Association of Malaysian Environment-Behaviour Researchers), ABRA (Association of Behavioural Researchers on Asians) and cE-Bs (Centre for Environment-Behaviour Studies), Faculty of Architecture, Planning \& Surveying, Universiti Teknologi MARA, Malaysia.

DOI: https://doi.org/10.21834/ajqol.v4i16.196 


\subsection{Introduction}

The growing interest in tourism that is environmentally responsible, socially and culturally sensitive, and economically viable is playing a significant role in the emergence of such tourism philosophies as ecotourism, pro-poor tourism, community-based tourism, responsible tourism and sustainable tourism (Simpson, 2007). Consequently, ecotourism has been widely espoused by practitioners and academics as an ideal form of tourism that can be applied in protected areas as it should possess a dominant nature-based element, environmental and socio-cultural sustainability requirements, economic or financial viability, learning and education components (Diamantis, 1999; Weaver, 2008), and is prescribed to provide high quality tourism experiences (Ross and Wall, 1999).

In an evaluation of ecotourism as a livelihoods strategy, it is important to recognize that the impacts identified will differ according to the perspective taken. A single-lens perspective is a notable deficiency of much previous research assessing ecotourism (Stronza, 2001). Often, from an industry perspective, tourism's impacts are mainly assessed in economic terms (Vajirakachorn and Nepal, 2014). Governments typically adopt this perspective, treating tourism like any other industry in the economy (Vajirakachorn and Nepal, 2014). This often results in unfavorable acceptance at the local level. Especially in the case of a marine park, economic factors must be in line with other important factors in governing protected areas i.e. environmental, social and institutional.

Based on the aforementioned issues, this study integrates institutional theory, ecotourism thinking and a Sustainable Livelihoods approach to investigate the relationships between institutional arrangements, native rights, and ecotourism for livelihoods sustainability. This study will focus particularly on the entitlement of the local community to be involved in the institutional arrangements that regulate ecotourism activities or other livelihoods strategies. It is crucial to examine how legal status can play a role in empowering a community by enabling them to participate in an institution that is representative and entitles them to have access to the decision-making process and knowledge of government decision-making processes.

\subsection{Literature Review}

\section{The ecological, social, and economic impacts of ecotourism}

In developing countries, some communities with land entitlements earn income from natural resource use rights and from renting or leasing land to tourism operators (Zeppel, 2006). However, without proper planning and best practice management, ecotourism can be a threat to the ecosystems in which it occurs (Honey, 1999). On the other hand, if meticulous planning and effective management are practiced, ecotourism, which is always associated with the promotion of conservation and development, will have the potential to solve many problems associated with tourism (Ross and Wall, 1999) and significantly change the operation of conventional mass tourism (Honey, 1999). Jenkins and Wearing (2003) have identified a range of positive and negative economic, environmental, social and cultural impacts associated with ecotourism in Australia. They indicated that the impacts from the improper 
management of ecotourism activities include the alteration and disturbance of wildlife habitats, indirect damage of vegetation, excessive hunting and fishing, erosion, marine impacts, pollution and hydrological changes to ground and surface water quality.

The impacts of ecotourism on the environment should also be viewed from economic and social standpoints because they will not only affect the ecological features that attract tourists but also affect the livelihoods of local people (Jenkins and Wearing, 2003; Tsaur et al., 2006; Tao and Wall, 2009). From an economic perspective, ecotourism can support funding for conservation and protection of the environment. On the other hand, from a social perspective, educational components of ecotourism can also encourage people (both visitors and locals) to have more appreciation of nature and encourage the local community to participate in nature preservation that will lead to community empowerment (Jenkins and Wearing, 2003; Tsaur et al., 2006). For instance, Lai and Nepal (2006) suggested that the lack of skills and knowledge of local people about ecotourism activities and their consequences can lead to an unreliable capacity to manage ecotourism development. Therefore, educational components of ecotourism, together with a participatory approach that recognizes traditional knowledge and good management and governance are important to ensure the accomplishment of local empowerment.

\section{Ecotourism as a livelihood strategy}

Ecotourism, probably the fastest-growing form of tourism in remote natural areas, provides an economic rationale for proponents of national parks although there are many critiques of its effectiveness in sustaining local people's livelihoods and, at the same time, conserving biodiversity. As referred to the definition of ecotourism in the earlier discussion, proponents of ecotourism often acknowledge the special relationships between indigenous people and natural areas. As the PA management paradigm has shifted, a protected well-managed ecotourism has become increasingly seen as a strategy to achieve cultural, environmental and economic sustainability for indigenous communities, especially in national parks.

However, many anthropologically oriented studies have looked at the potential roles of ecotourism negatively. Indeed, many have argued that ecotourism is only a strategy for conservationists to accomplish their goals (West et al., 2006). From the conservationists' point of view, there are critiques about ecotourism being misrepresented in development projects (e.g. eco-resorts which do not comply with ecotourism criteria). Such misrepresentations have ultimately led to environmental degradation and affected the genuineness of ecotourism. Despite these critiques about the existence of ecotourism in parks, many studies have shown that ecotourism has raised interest in tourism that is concerned with the environment, communities, and sustainability (Stronza and Gordillo, 2008; Simpson, 2009; Camargo et al., 2007; Fuller et al., 2007). One of important roles of ecotourism is that it can assist in building community capacity and, thereby, to enhance benefits for local communities (Aref et al., 2009; Laverack and Thangphet, 2009; Simpson, 2009).

Based on Tao and Wall's (2009) studies on tourism as a livelihood strategy, development of local people can occur through livelihood diversification e.g. tourism introduced as an additional source of livelihoods. Ecotourism can provide opportunities for local people in PAs 
to participate in new livelihood activities, which involve indigenous people either utilizing natural resources and traditional lands (with sustainable use of resources) or selling access to their unique way of life to gain income from ecotourism. This will involve nature and cultural conservation and, at the same time, improve livelihoods (Zeppel, 2006). Furthermore, appropriate training and education are important for local people to take advantage of such opportunities. Thus, capacity building is commonly required to enable them to get involved in ecotourism activities or management. Nepal (2002) indicated that a good example of partnership between a park authority and local people can be found in Canada, where the effective involvement of local people in some national parks has led them to have more options to decide for themselves in terms of legal matters, economic opportunities, and social and cultural justice. However, according to Laverack and Thangphet (2009), there is still lack of successful evidence of practical approaches in different cultural contexts.

\section{Sustainable Livelihoods Framework (SLF)}

The advantage of adopting a SL approach is the strengths of the framework that is used to draw in conventional analyses (economic, environmental, social, and institutional) to understand the complexity of livelihoods, the influences on poverty, people's options regarding sustaining their livelihoods and to identify where interventions can best be made (Figure 1) (Baumann, 2000; Farrington, 2001).

An analysis of assets is fundamental to understanding the options that are accessible to households and communities, and to the recognition of the assets that people possess and how they change over time. Five capital assets (assets pentagon) are identified in the framework: human, physical, social, natural, and financial. Moreover, social differences are recognized in the analysis of the accessibility to and control over assets. Options are further determined by policies, institutions and processes (such as the role of government and the private sector, institutional and traditional culture, gender etc.) with which people engage (Baumann, 2000). A concurrent analysis of institutional structures and processes at microand macro-levels is vital for understanding opportunities and constraints in the wider structural features that might influence livelihoods in a particular place (Scoones, 2009). It is assumed that people pursue a variety of livelihoods outcomes (health, food security, more income etc.).

An analysis of outcomes focuses on achievements, indicators and progress that eventually provide an understanding of what contributes to the well-being of people (Cahn, 2002). Furthermore, it is important to understand the diverse and dynamic livelihoods strategies to identify the best time to intervene. An analysis of livelihoods strategies provides important information on how people negotiate on appropriate processes and structures to implement the strategies. Finally, an analysis of the vulnerability context helps one to understand how people adapt and cope with events that are beyond their control. In the proposed study, vulnerability will be addressed through a focus on the establishment of marine parks and how it influences the overall livelihoods system. In addition, the analysis should examine the role of institutional processes and structures required to handle and reduce vulnerabilities and how the vulnerabilities influence processes and structures.

However, for the purpose of this study, the analysis using SL focused on the institutional 
processes and structures (i.e. native customary rights), livelihoods strategies (i.e. ecotourism), livelihoods outcomes (i.e. community development) and their interrelation.

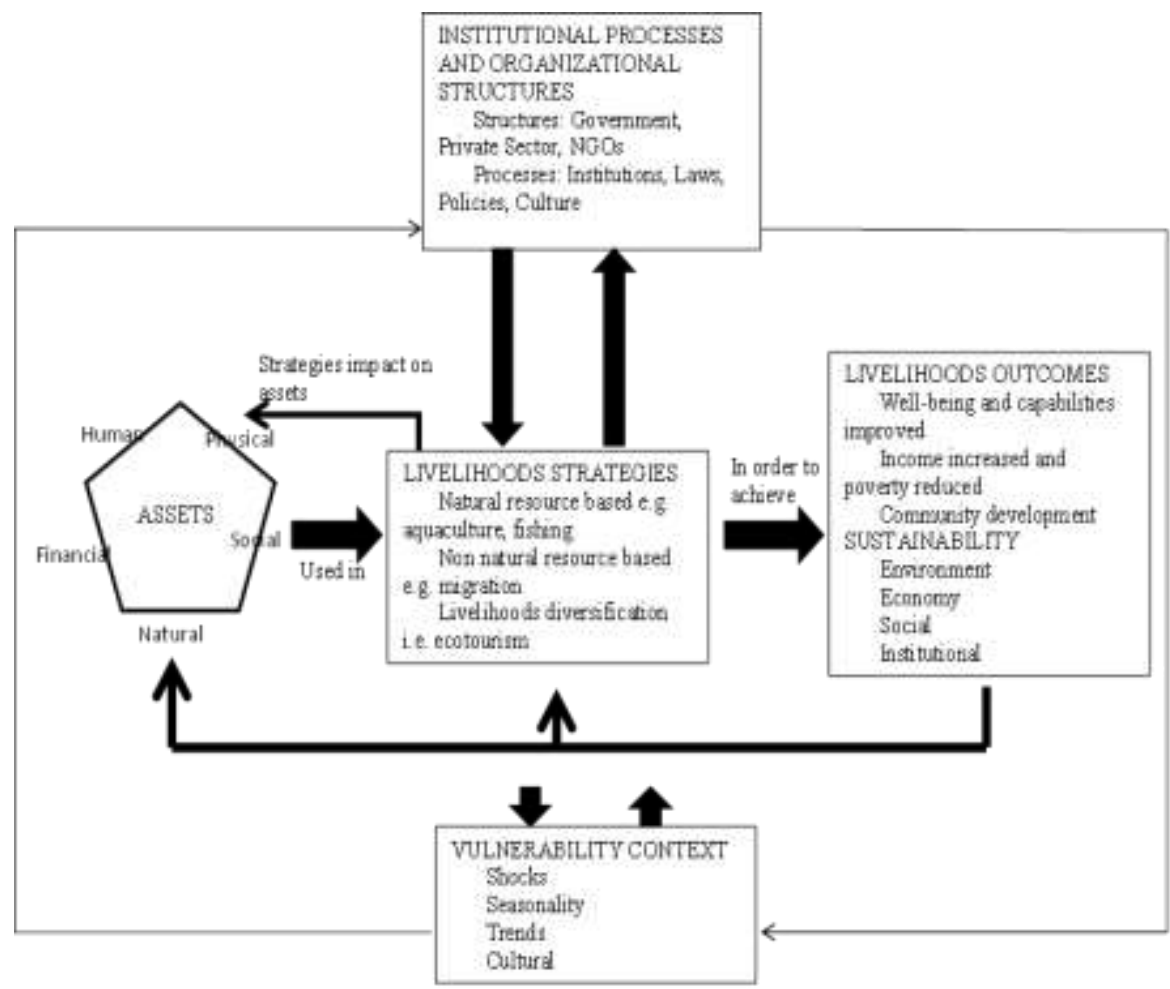

Figure 1: Sustainable Livelihoods Framework (SLF) (adapted from Scoones, 1998; Cahn, 2002)

\subsection{Methodology}

A priority is given to qualitative methods as the research involved an ethnographic case study to observe and to collect data, especially in regards to the issues of institutional structures and processes, the social and cultural attributes of marine communities, livelihoods and native rights issues that are easier to describe through qualitative analysis and more comprehensible through qualitative interpretation. Although qualitative approaches dominate the research design, quantitative measures are also used. Methods such as content analysis and analysis of secondary data incorporate statistical techniques using SPSS. Similarly, questions requiring quantitative responses, such as demographic information on household size and ethnicity, were asked on the household survey as a means of gathering data for statistical analysis. Quantitative analysis of survey data is important, especially when needed to complement the qualitative results and to analyze diverse opinions. 


\section{Fieldwork}

The fieldwork was conducted for three months from September to December 2012 in the largest marine park in Malaysia, the Tun Sakaran Marine Park, which is located within Semporna district, Sabah. TSMP is situated at the entrance of Darvel Bay in Semporna, off the southeast coast of Sabah, Malaysia (Figure 2).

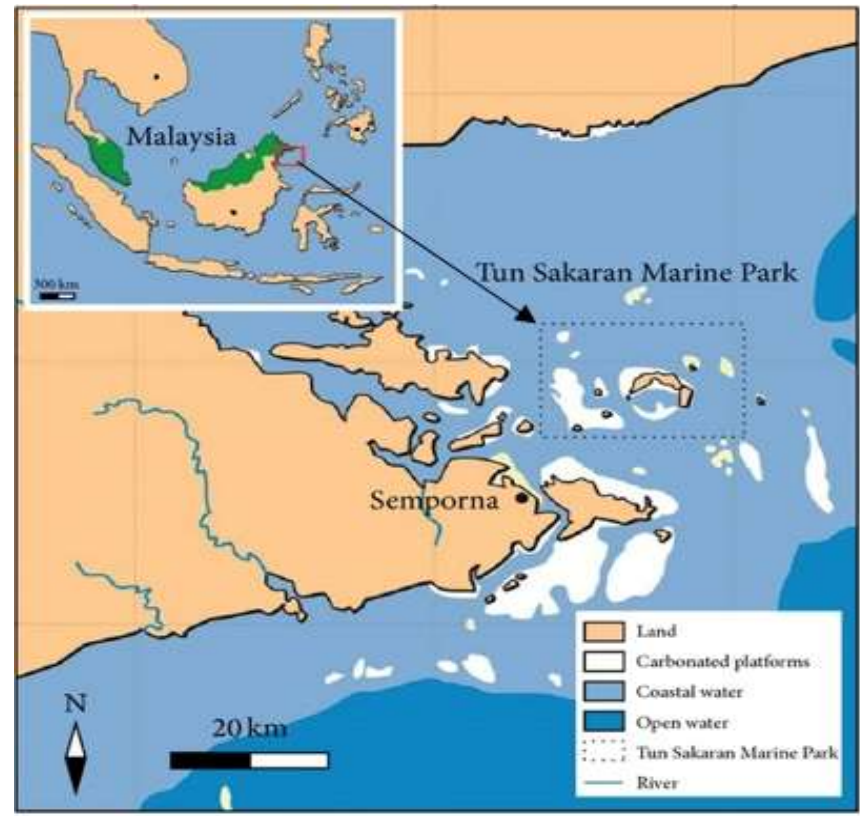

Figure 2: Location of the Tun Sakaran Marine Park in Malaysia

Three ethnic groups live in TSMP: Bajau, Bajau Laut and Suluk. Although Bajau and Bajau Laut speak the same Sama language (perhaps with different dialects) and are believed to be from the same origins, they are different in terms of the places they lived in, the livelihoods strategies they choose, their perceptions of their lives and the institutional structures that shape their livelihoods. At the same time, Suluk people are distinctively different from Bajau and Bajau Laut, especially in terms of language and livelihood activities. In addition, the three ethnic groups live in the islands only among their own people, with the Bajau community living permanently in Selakan, the Bajau Laut scattered around Maiga, Bodgaya, Boheydulang and Sibuan, and the Suluk people found especially in Sebangkat (the great majority live on the reef-top settlement), and some villages in Bodgaya and Boheydulang. Different islands also support different livelihood activities: Sebangkat and Selakan are significant for seaweed farming, and Bodgaya and Boheydulang possess better soil for gardening. With this in mind, it was necessary to devise a sampling method to represent each ethnic group and island. 


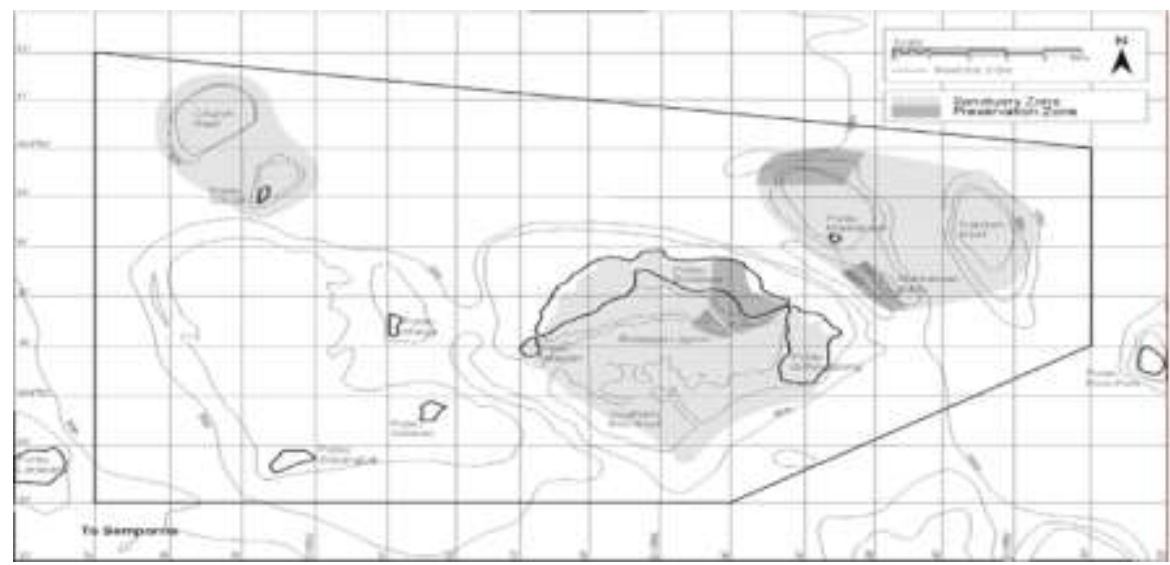

Figure 3: Map showing the eight islands and associated reefs

(Source: SIP Management Plan, 2001)

Proportionate stratified random sampling was chosen to ensure representation of the three ethnic groups in all of the six inhabited islands. 79 households were interviewed i.e. approaching half of all households in the park (total household $=184$ ). From the interviews, it was found that the 28 respondents of Bajau ethnicity represent 179 people, the 20 Bajau Laut respondents represent 145 people, and the 31 Suluk households represent 209 people. The household survey was designed to obtain information about respondents' livelihood practices (before and after park establishment), demographic characteristics, institutional issues especially regarding local participation in park management and the relationship with native customary rights, and respondents' perceptions of ecotourism. Therefore, the interview questions were divided into four groups: demography; livelihoods; institutional structures and processes, and ecotourism. The four themes were each addressed through both closed and open-ended questions. Open-ended questions allow the researcher to hear respondents' opinions in their own words and minimize external influences from the interviewer or from the research instrument itself.

\subsection{Results}

\section{Attitudes towards ecotourism}

Community participation in ecotourism activities is crucial in order to elevate their economic status. One might well ask "What kind of participation?" What level of participation is appropriate? Based on the TSMP case, community participation should be encouraged to occur at the top rungs that are classified as 'citizen power', including partnership, delegated power and citizen control. Although the highest level, citizen control, is not plausible since TSMP is a marine park under the state's administration, partnership and delegated power, if well implemented, could be instrumental in the successful development of ecotourism in TSMP. The reason for this is straightforward: some members of the community are entitled 
to native rights, making them important stakeholders in any kind of development in TSMP.

The results of the fieldwork demonstrate clearly that ecotourism is not yet implemented in ways that involve local people who depend for their livelihoods on harvesting marine resources. Therefore, it was not possible to examine the community's level of participation. Nor was it plausible to explore how institutional arrangements influence partnerships in ecotourism except for the realization that, to date, local involvement in ecotourism has been inhibited to the extent that it does not exist. However, it is important to examine people's attitudes towards potential ecotourism development in TSMP since this information could be used to guide and be an indicator of the community's aspirations to sustain themselves through ecotourism. Furthermore, it is important to appreciate the local understanding of ecotourism so that local residents will not be sidelined in future ecotourism development.

Based on the household survey, when asked about their understanding of ecotourism, $70 \%$ answered 'Do not know', $24 \%$ answered 'It is about job opportunities', and 5\% answered 'Holiday' (Table 1). This shows that local people are not well informed about ecotourism and this may be one reason for the failure to incorporate ecotourism into existing livelihoods so far.

\begin{tabular}{|l|l|l|}
\hline & Frequency & Percent \\
\hline Do not know & 55 & 70 \\
\hline Job opportunity & 19 & 24 \\
\hline Holiday & 4 & 5 \\
\hline Protect ecosystem & 1 & 1 \\
\hline
\end{tabular}

Table 1: Communities' understanding of ecotourism

It was only possible to ask questions about ecotourism after the concept had been introduced to potential respondents by members of the research team. Based on Table 2, importantly, $89 \%$ of respondents agreed and $4 \%$ strongly agreed that ecotourism could be incorporated into existing livelihood activities to enhance their well-being. Only $1 \%$ disagreed and $6 \%$ were undecided. Those with a negative attitude towards ecotourism believed that they would not get benefits, being very skeptical about the involvement of Sabah Parks.

Table 2: Communities' opinions towards ecotourism development in TSMP.

\begin{tabular}{|l|l|l|}
\hline & Frequency & Percent \\
\hline Strongly disagree & 0 & 0 \\
\hline Disagree & 1 & 1.3 \\
\hline Undecided & 5 & 6.3 \\
\hline Agree & 70 & 88.6 \\
\hline Strongly agree & 3 & 3.8 \\
\hline Total & 79 & 100.0 \\
\hline
\end{tabular}

The household survey also revealed that $85 \%$ of respondents hoped to see more tourists coming to TSMP in the future. These positive attitudes of local communities toward 
incorporating ecotourism into their existing activities demonstrate that they will welcome efforts to improve their livelihoods. Furthermore, they emphasize that efforts must be made to give priority to local well-being as mentioned by the important person of $\mathrm{Kg}$. Selakan as follows:

"There are lots of good thing about ecotourism that I know of. It can protect our marine resources, increase our income, and provide the opportunity for our younger generation to get a better job. We are villagers, we do not have proper education, but we do not want our next generation to inherit what we do today. Life is so hard nowadays (referring to park rules)."

The respondent continued by saying:

"...we, sea people, have had enough of eating fish. We hope our government can provide better jobs that will allow our children to taste chicken or beef."

In order to achieve local hopes about ecotourism, participation is required along with the delegation of power. Another respondent, representing a perspective held by a number of other informants, expressed caution about involving the local communities:

"We fully support if they want to develop ecotourism here in TSMP. But it must be done with the objective to incorporate ecotourism into the community's existing livelihoods activities in order to sustain our livelihoods. If the communities are not involved during planning, there is a huge possibility that we will be sidelined again (reference to the previous attempt to develop a resort in TSMP). We are not against development, but they always do something without consulting and informing us, and that is suspicious enough. Maybe they do not want us to get involved."(Subject \#31, 2012)

However, a contradictory comment was made by a Sabah Parks officer that showed misunderstanding, miscommunication, and a hostile relationship between the park authority and TSMP communities. His significant comments were made in relation to the abandoned tourism project in TSMP as follows:

"The villagers were totally depending on government help. They could not do anything on their own. They did not go to school and even their leaders were uneducated. When we wanted to build a resort there, they protested as they said the land was under native title application. But there was no proof. They always want to protest. If they continue like this, I do not think that we can develop TSMP into an ecotourism destination." (Subject \#SH05, 2012).

The comments by the official were sensible with respect to education and people's dependency on government assistance. For instance, most of the older villagers did not go to school and, with limited knowledge, livelihoods options are very limited. This explains the dependency on government assistance and subsidies. However, from the fieldwork and household survey, the situation can also be explained by the lack of initiatives from Sabah Parks and other responsible authorities to empower communities in TSMP to be more independent in terms of improving their overall well-being. Most assistance has been short term, such as a one-off diesel subsidy, one-off boat and engines subsidy and so forth. Although these helped to alleviate burdens at the time, these kinds of assistance were only temporary and did not build local capacities in enduring ways. Education and training are needed for long-term survival, for instance in entrepreneurship regarding seaweed production or other marine-based products, including tourism. 


\subsection{Status of livelihoods and changes before and after park establishment}

Based on Figure 4, almost half $(47 \%, n=37)$ indicated that their livelihood activities had not changed in any way, although $30 \%$ said that their livelihoods activities and income had decreased substantially. One tenth $(9 \%, n=7)$ suggested that the question was not applicable to them as they were mostly women who were basically housewives. For Bajau and Bajau Laut, men are the head of the family and are expected to be the breadwinner. In the Suluk community, women also help in seaweed and gardening activities. Only $4 \%(n=3)$ said that their livelihood was currently good and they engage in alternative livelihood activities, such as running a small business, fish farming or operating their own seaweed farm.

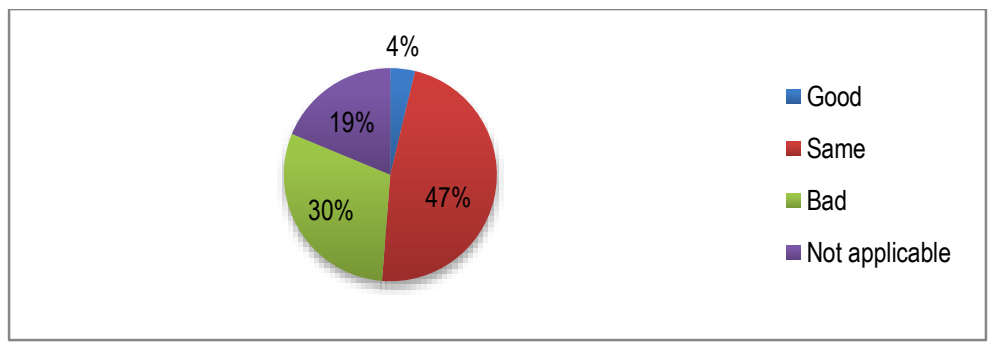

Figure 4: Status of existing livelihoods activities

Figure 5 indicates that approaching a half $(43 \%, n=34)$ believed that there had been few changes in their circumstances in the preceding ten years, whereas $37 \%(n=29)$ perceived negative changes and $20 \%(n=16)$ said there had been positive changes. Again, the negative evaluations reflect livelihood deterioration due to fish bombing, poor seawater conditions, adverse effects of zoning and reduced accessibility to the fishing area, and unequal distribution of benefits. The positive perceptions again encompass increased safety, benefits from conservation and increased government assistance.

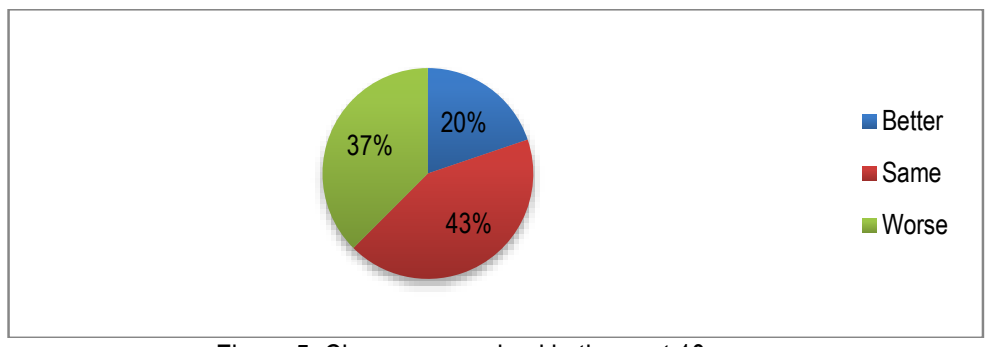

Figure 5: Changes perceived in the past 10 years

Further analyses were undertaken in search of possible difference between the ethnic groups. According to one-way ANOVA and the post hoc test (Table 3 and Table 4), significant differences were found in association with ethnicity: Bajau respondents were more vocal in expressing opinions/perceptions than Bajau Laut and Suluk who were more reserved in their 
responses. Again, most of Bajau Laut and Suluk respondents answered 'I don't know', 'nothing', or 'the same' when asked for their opinions in Likert-type questions. Interviews and open-ended questions resulted in more revealing responses. For example, Bajau Laut and Suluk respondents expressed their views as follows:

I never agreed with the park establishment. But we are Bajau Laut. We have no rights to say no because we have not acquired a legal document. We are afraid of being displaced.

At the end of the day, we do not care anymore about the park.' (Subject \#050)

'Our lives have always been difficult. Before, after (park establishment), the same. Nothing more we can do except to go on.' (Subject \#026)

'We were thankful to the Malaysian government for accepting us here. We do not want to go back to the (southern) Philippines. Life is even worse there: you can get killed easily. We feel safe here. (Subject \#072)

Bajau people with NCR were more vocal in expressing their opinions than the socially marginalized Bajau Laut with no entitlements. The Suluk were once recognized as a superior group in the Sulu-Sulawesi Sea, but their status as immigrants, both legal and illegal, undermined their right and willingness to express their feelings.

Table 3: One-way ANOVA test showing differences with ethnicity

\begin{tabular}{|l|l|l|l|l|l|l|}
\hline \multicolumn{2}{|c|}{} & Sum of Squares & df & Mean Square & F & Sig. \\
\hline \multirow{4}{*}{ Better } & Between Groups & .761 & 2 & .380 & 2.538 & .086 \\
\cline { 2 - 8 } & Within Groups & 11.391 & 76 & .150 & & \\
\cline { 2 - 8 } & Total & 12.152 & 78 & & & \\
\hline \multirow{4}{*}{ Wame } & Between Groups & .033 & 2 & .016 & .064 & .938 \\
\cline { 2 - 8 } & Within Groups & 19.335 & 76 & .254 & & \\
\cline { 2 - 8 } & Total & 19.367 & 78 & & & \\
\hline \multirow{3}{*}{ Worse } & Between Groups & 4.590 & 2 & 2.295 & 11.804 & .000 \\
\cline { 2 - 8 } & Within Groups & 14.777 & 76 & .194 & & \\
\cline { 2 - 8 } & Total & 19.367 & 78 & & & \\
\hline
\end{tabular}

*The mean difference is significant at the $p<0.05$.

Table 4: Post-hoc test to determine which group is significantly different from the others

\begin{tabular}{|l|l|l|l|l|l|}
\hline \multirow{2}{*}{ Dependent Variable } & (I) Ethnic_3 & (J) Ethnic_3 & Mean Difference (I-J) & Std. Error & Sig. \\
\hline \multirow{5}{*}{ Better } & & & & \\
\hline \multirow{3}{*}{ Bajau } & Bajau Laut & .221 & 113 & 131 \\
\cline { 2 - 6 } & Suluk & .192 & 101 & 144 \\
\cline { 2 - 6 } & Bajau Laut & Bajau & -.221 & 113 & 131 \\
\cline { 2 - 6 } & Suluk & -.029 & 111 & .963 \\
\cline { 2 - 6 } & Suluk & Bajau & -.192 & 101 & 144 \\
\hline
\end{tabular}




\begin{tabular}{|c|c|c|c|c|c|}
\hline & & Bajau Laut & .029 & .111 & .963 \\
\hline \multirow{6}{*}{ Same } & \multirow{2}{*}{ Bajau } & Bajau Laut & -.029 & .148 & .980 \\
\hline & & Suluk & .023 & .132 & .983 \\
\hline & \multirow{2}{*}{ Bajau Laut } & Bajau & .029 & .148 & .980 \\
\hline & & Suluk & .052 & 145 & .932 \\
\hline & \multirow{2}{*}{ Suluk } & Bajau & -.023 & .132 & .983 \\
\hline & & Bajau Laut & -.052 & .145 & .932 \\
\hline \multirow{6}{*}{ Worse } & \multirow{2}{*}{ Bajau } & Bajau Laut & $.543^{*}$ & .129 & .000 \\
\hline & & Suluk & $.474^{*}$ & .115 & .000 \\
\hline & \multirow{2}{*}{ Bajau Laut } & Bajau & $-.543^{*}$ & 129 & .000 \\
\hline & & Suluk & -.069 & .126 & .848 \\
\hline & \multirow{2}{*}{ Suluk } & Bajau & $-.474^{*}$ & .115 & .000 \\
\hline & & Bajau Laut & .069 & 126 & .848 \\
\hline
\end{tabular}

${ }^{*}$ The mean difference is significant at the $p<0.05$. Tukey HSD test.

In summary, findings concerning attitudes towards the park, perceptions of their livelihoods status and perception concerning livelihood changes over the preceding ten years were related and showed a similar pattern of responses. Basically, Bajau Laut and Suluk were reluctant to respond to Likert-scale questions and commonly gave neutral responses reflecting their perceived legal status. However, they were more able to state their concerns in other data acquisition formats. On the other hand, Bajau, who often had NCR, were more willing to state an opinion but they, too, commonly held negative perceptions towards the park.

\subsection{Discussion}

Customary laws are a very important factor that should protect a community's rights to land and other property on that particular land. Indirectly, when a community has their rights recognized by law, it should also ensure that they could never be sidelined in park decisionmaking processes. Based on the findings of the study, NCR is marginally recognized as an influence in TSMP institutional arrangements. The park management plan indicates that comanagement will be introduced, hence the foundation of a Local Community Forum (LCF) to represent those in the community with NCR. Unfortunately, engagement with LCF only occurred before and a few times after park establishment. A very important member of LCF indicated in an interview his disappointment that Sabah Parks had stop consulting them prior to making decisions about the park. He added that prior to the park's official establishment, they were given priority treatment in every discussion and decision-making process. They filed ten pledges to be fulfilled if Sabah Parks wanted the community to give consent to the proposed TSMP. Sabah Parks only agreed to six of the pledges. Nonetheless, LCF proceeded to give their consent because of the promises made by Sabah Parks i.e. comanagement, ecotourism and a hatchery project. At the time of interview in 2012, the respondents stated that it had been five years since they had been last invited to Sabah Parks meetings. 
The park authority's failure to consult with local communities on park management and development are detrimental to relationships among stakeholders and the management of the park. Hostility between the park authority and local people is fostered, as well as negative perceptions towards conservation and ideas about sustainable resource use. Disempowerment of the community further marginalizes poor people. These negatives consequences could be reduced if the park authority would give extra attention to educating and involving local people in park management. The participatory events organized by the researcher and survey results revealed widespread negative perceptions towards the park authorities.

The most significant consequence of the failure to recognize those with NCR is that pending development plans are thwarted due to long-standing problems of ignorance and, in consequence, local resistance. For example, in an interview with a Sabah Parks officer, it was discovered that some projects have been cancelled or postponed because of disapproval from the community. The officer argued that many of those who disagreed with a project did not justify their action with claims of legal entitlement to native land, and gave no proof of a grant or other evidence of belonging. From the perspectives of Sabah Parks, communication and consultation with the local community will only complicate matters. As a result, they adopt a controller role as the state's government agency rather than acting as a facilitator to involve relevant stakeholders in developing and managing the park. On the other hand, from the community's perspective, the argument has been made that they inherited the land and the sea from their ancestors. This can be seen from their gardens, their ancestors' graves and the seaweed farms that they ran for many years before park establishment. Some who did not possess valid grant or native title argued that they claimed the land under NCR long before park establishment and suspected that their application was still pending due to the gazetting of the park.

The two different perspectives can only be resolved through a meaningful and ongoing discussion, consultation and sharing of information between the park and people. NCR entitlement means that holders have the right not only to stay in TSMP, but also to be involved in managing it, i.e. determining access and control over resource use. They should benefit from whatever opportunities the park has to offer. For example, there was strong support for the introduction of ecotourism development in TSMP if it is locally managed. Some respondents expressed interest in homestays, boat rentals, cruises and other sea-venture activities but most emphasized that they would only agree to such activities if the power and benefits are equally shared. This shows that the community was well aware of what was happening around them, but they were not sufficiently well informed and well educated to devise their own means of influencing the institutional arrangements and management actions effectively.

\subsection{Conclusion}

An SL approach is promoted in an attempt to eradicate poverty among rural, often marginalized, communities by putting people's priorities first, linking sectors both vertically and horizontally and from local to higher levels, building capacity and recognizing ownership 
of land or other properties, thereby moving the system in the direction of sustainability (Keely, 2001). In accordance with this, the institutional process, including customary laws, and the organizational structure (park management arrangements) have been studied in order to investigate how they can be used to influence the livelihoods system. Based on previous discussions, if NCR is truly recognized, it could be used to stimulate the acquisition of local feedback, thereby changing how institutions work, eventually contributing to organizational change (institutional arrangements). For instance, representatives from the people with NCR entitlement could be incorporated into the organizational structure of park management, allowing them to participate actively and meaningfully in information sharing and the decisionmaking process. Community participation is necessary to inform the management team about the situation on the ground and also for the community to be well informed on what is happening outside of their jurisdiction. Through information sharing and education, understanding and trust could be created, possibly resulting in mutual accommodation among stakeholders. Management efficiency could be increased through provision of a more productive environment, especially in terms of livelihoods and marine conservation in TSMP.

The objectives of the organization in managing TSMP should be to improve the wellbeing of communities and to conserve the ecosystems and natural resources of the park. Once all stakeholders are in unison to work on these objectives, feedback would inform the institution to change management strategies accordingly. Furthermore, the dynamic nature and complexity of the marine environment will influence the feedback process and the movement towards sustainable livelihoods through institutional change.

\section{Acknowledgement}

We are grateful to the TSMP's communities, their hospitality, care, and kindness made this study possible. We are greatly indebted to our local research assistants, Sakkah Jauhali and Jalil Mapait, whose knowledge, wisdom, and tremendous help had made the impossible possible. This research was financially supported by the Ministry of Higher Education Malaysia, the University of Waterloo Graduate Studies Office (UW-GSO), and the University of Waterloo's Faculty of Environment Graduate Scholarship Award.

\section{References}

Aref, F., Redzuan, M., \& Gill, S.S. (2009). Dimensions of community capacity building: A review of its implications in tourism development, Journal of American Science, 5 (8), 74-82.

Baumann, P. (2000). Sustainable livelihoods and political capital: Arguments and evidence from decentralisation and natural resource management in India. ODI Working Paper, 136. London: ODI.

Cahn, M. (2002). Sustainable livelihoods approach: concept and practice. 3rd Biennial Conference of the International Development Studies Network of Aotearoa, New Zealand.

Camargo, B., Lane, K., \& Jamal, T. (2007). Environmental Justice and Sustainable Tourism: The missing cultural link. The George Wright Forum, 24(3), 70-80. 
Diamantis, D. (1999). The concept of ecotourism: Evolution and trends. Current Issues in Tourism, 2(2-3), 93-122.

Farrington, J., (2001). Sustainable livelihoods, rights, and the new architecture of aid. Natural Resources Perspective, 69. London: ODI.

Fuller, D., Caldicott, J., Cairncross, G., \& Wilde, S. (2007). Poverty, indigenous culture and ecotourism in remote Australia, Development, 50 (2), 141-148.

Honey, M. (1999). Ecotourism and sustainable development: Who owns paradise? Washington: Island Press.

Jenkins, J. \& Wearing, S. (2003). Ecotourism and protected areas in Australia. In Ecotourism policy and planning, Fennel, D.A., \& Dowling, R.K. (eds).UK: CABI Publishing.

Keeley, J. E. (2001). Influencing Policy Processes for Sustainable Livelihoods: Strategies for change. Lessons for Change in Policy \& Organisations, No. 2. Brighton:Institute of Development Studies.

Lai, P., \& Nepal, S. (2006). Local perspectives of ecotourism development in Tawushan Nature Reserve, Taiwan, Tourism Management, 27(6), 1117-1129.

Laverack, G., \& Thangphet, S. (2009). Building community capacity for locally managed ecotourism in Northern Thailand, Community Development Journal, 44(2), 172-185.

Mcneely, J. A. (1995). Expanding Partnership in Conservation. Washington DC: Island Publications.

Nepal, S. K. (2000). Tourism, national parks and local communities. In Tourism and National Parks - Issues and Implications. R.W. Butler and S. W. Boyd. (eds). Chichester: John Wiley \& Sons.

Ross, S., \& Wall, G. (1999). Ecotourism: Towards congruence between theory and practice, Tourism Management, $20(1), 123-132$.

Scoones, I. (1998). Sustainable rural livelihoods: A framework for analysis. University of Sussex, UK: Institute of Development Studies.

Scoones, I. (2009). Livelihoods perspectives and rural development. Journal of Peasant Studies, 36(1), 1-26.

Semporna District Office. (2012). Diving sites. (Semporna District Office, Producer) Retrieved September $16^{\text {th }} 2012$ from http://ww2.sabah.gov.my/pd.sprn/sipadan.html

SIDP. (2005). Community action for sustainable use and conservation of coral reefs. SIDP News (1). Sabah: UK Department for Environment, Food and Rural Affairs.

Simpson, M. C. (2007). An integrated approach to assess the impacts of tourism on community development and sustainable livelihoods, Community Development Journal, 44(2), 186-208.

SIP Management Plan. (2001). Semporna Islands Project (SIP) Management Plan. Sabah: European Community.

Spadi, F. (2003). Pulau Ligitan and Pulau Sipadan: New Parameters for the Concept of Dependency in the Maritime Environment? The ICJ Judgment of 17 December 2002, The International Journal of Marine and Coastal Law, 18, 295-310.

Stronza A. (2001). Anthropology of tourism: forging new ground for ecotourism and other alternatives, Annual Review of Anthropology, 30, 261-283. 
Abu Bakar, N.A., \& Wall, G. / Asian Journal of Quality of Life (AjQoL), 4(16) May/Aug 2019 (pp.58-73)

Stronza, A., \& Gordillo, J. (2008). Community views of ecotourism, Annals of Tourism Research, 35(2), 448-468.

Tao, T. C. H., \& Wall, G. (2009). A livelihood approach to sustainability, Asia Pacific Journal of Tourism Research, 14(2), 137-152.

The Malaysian Times (2012). Illegal immigrants causing simmering resentment in Sabah. (The Malaysian Times, Producer) Retrieved 31st January 2014 from http://www.themalaysiantimes.com.my/illegal-immigrants-causingsimmering-resentment-in-sabah/

Tsaur, S., Lin, Y., \& Lin, J. (2006). Evaluating ecotourism sustainability from the integrated perspective of resource, community and tourism, Tourism Management, 27(4), 640-653.

Vajirakachorn, T. \& Nepal, S. K. (2014). Local perspectives of community-based tourism: case study from Thailand's Amphawa Floating Market, International Journal of Tourism Anthropology, 3 (4), 342 - 356.

Weaver, D. (2008). Ecotourism (2nd ed). Australia: John Wiley \& Sons.

West, P., Igoe, J., \& Brockington, D. (2006). Parks and peoples: The social impact of protected areas, Annual Review of Anthropology, 35, 251-277.

Zeppel, H. (2006). Indigenous ecotourism: Sustainable development and management. UK: CABI International. 